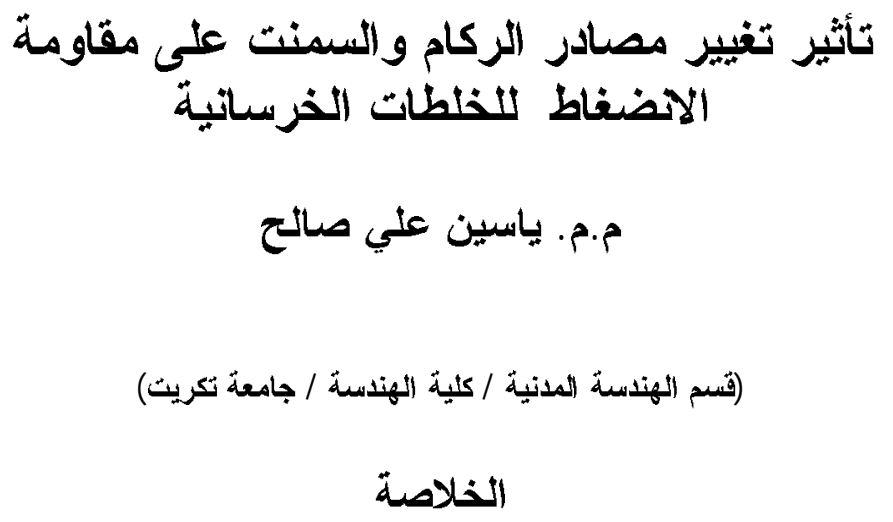

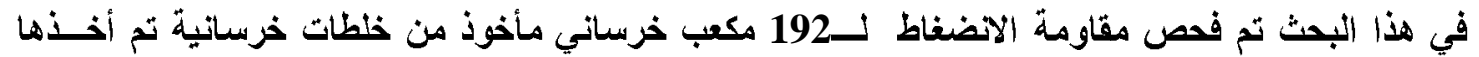

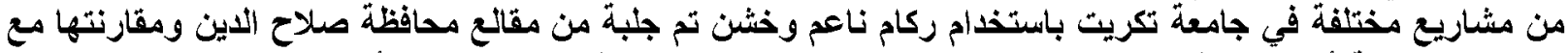

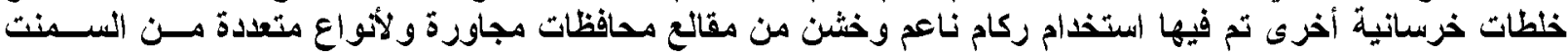

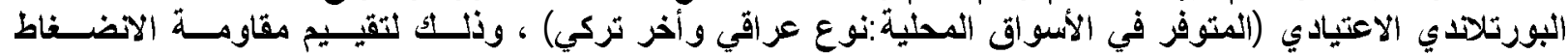

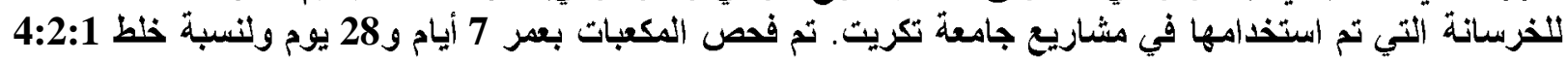
ونسبة ماء السنت مساوية لــانية (0.45).

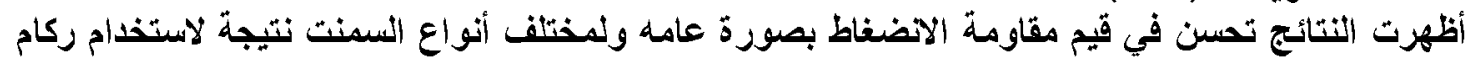

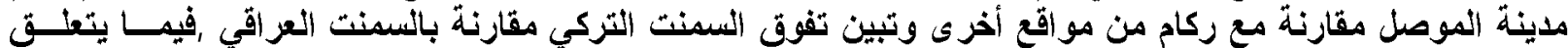
بمقاومة الاضضغاط. كلمات الالالة: - السمنت، الخلطة الخرسانية ، مقاومة الانضغاط

\title{
Influence of Aggregate and Cement Source on the Compressive Strength of Concrete Mixes
}

\author{
Asst. Lecturer. Yaseen Ali Salih \\ (Civil Eng., Eng. College, Tikrit University)
}

\begin{abstract}
In this research, (192) concrete cubes were taken from different concrete mixes incorporating coarse and fine aggregate from four different sources with two types of cement; Iraqi cement \& Turkish cement. The compressive strength of these cubes was examined to know the most suitable materials to product good concrete for use in the projects of Tikrit University. The results indicate that, the aggregate from Al-Mosul source gives compressive strength higher than the aggregate from other sources. The Turkish cement gives compressive strength higher than that given by Iraqi cement.
\end{abstract}




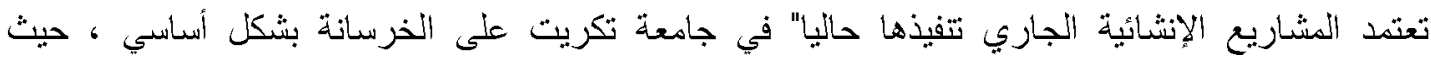

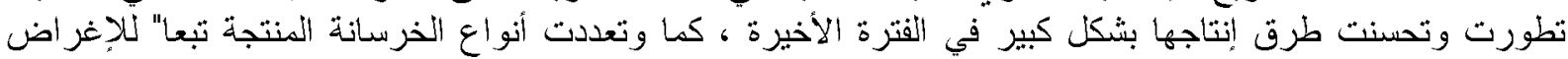

المستعملة من اجلها.

ومن خلال العمل في الإشراف على تنفيذ المشاريع الإنشائية الجاري تتفيذها في الجامعة لوحظة تباينا"

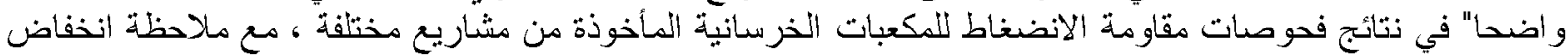

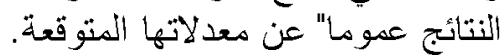

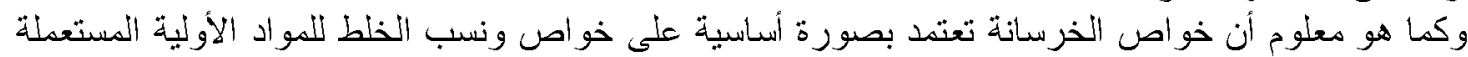

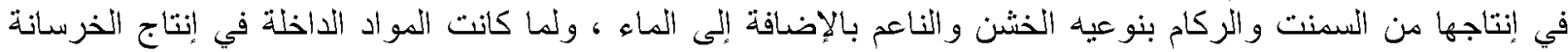

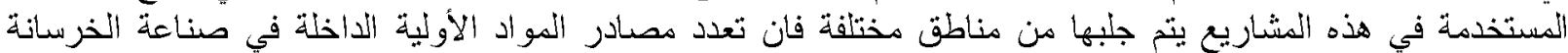

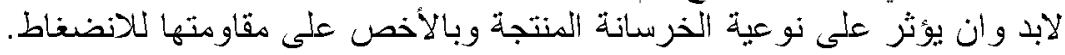

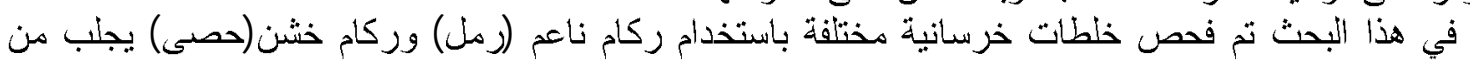

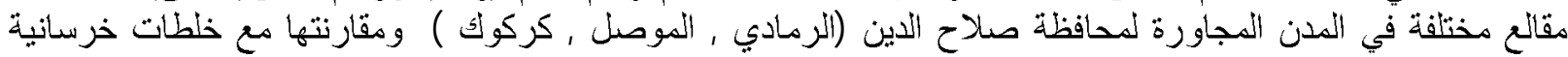

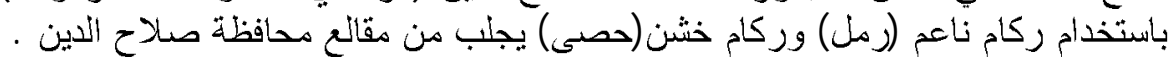

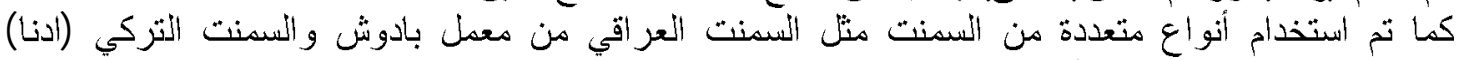

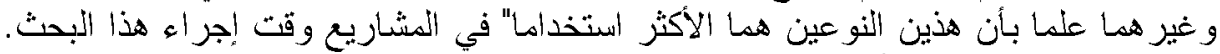

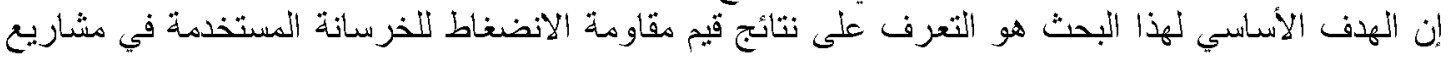

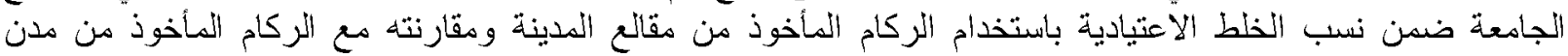
مجاورة وضمن الفترة التي اجري فيها هذا البحثة.

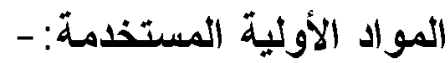

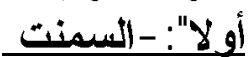

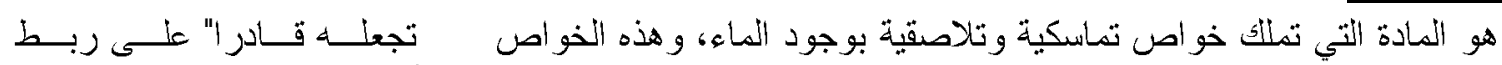

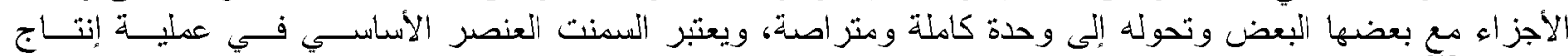

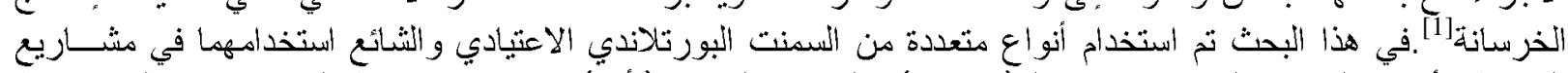

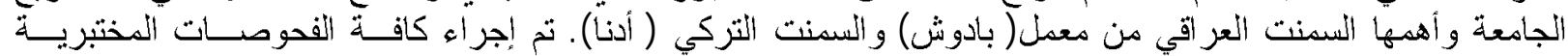

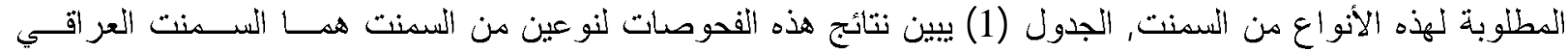
و السمنت التركي.علما" إن هذه القحوصات أجريت بموجب المو اصفة القياسية العر اقية رقم (5) لسنة 1984م.

\section{ثانيا': -الركام}

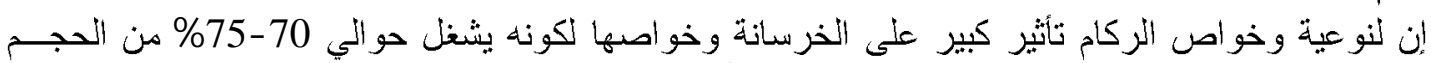

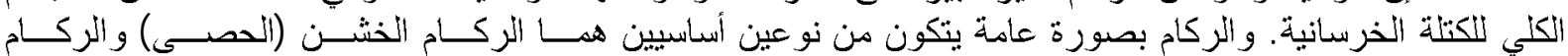

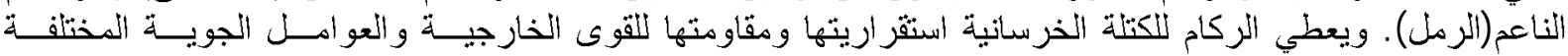

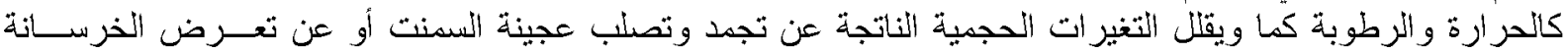

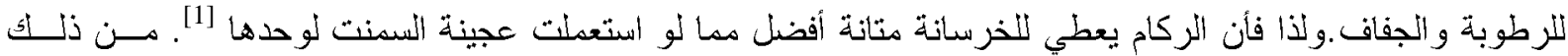

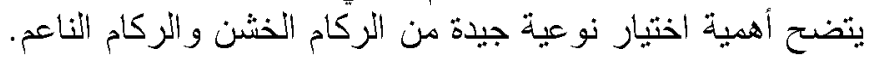

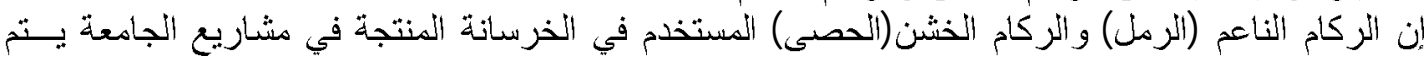

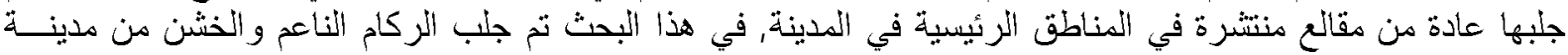

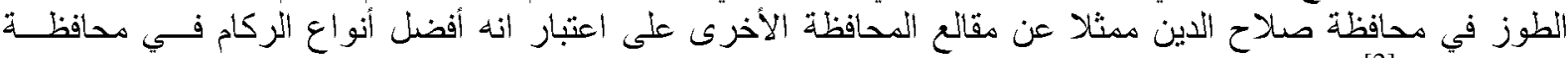
صلاح الدين [2] فئن

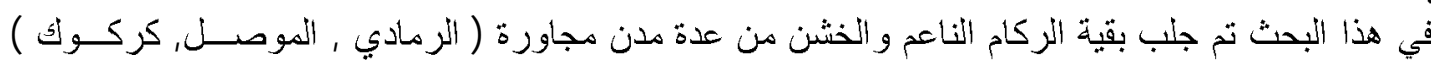

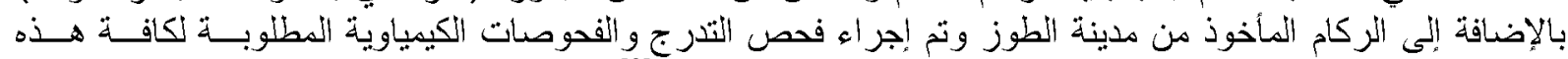

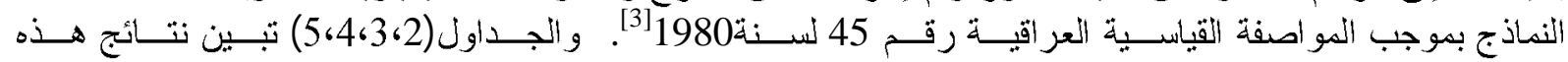
الفحوصات.و الثكلان (1 و 2 يوضحان التحليل المنظلي للركام الخشن و الركام الناعم على التو التي. 


\begin{tabular}{|c|c|c|c|}
\hline \multirow{2}{*}{ مיق.ق رقّم(5)1984 } & \multicolumn{2}{|c|}{ نوع السمنت } & \multirow{2}{*}{ أسم الفحص } \\
\hline & |السمنت المعر أقي & السمنت التركي & \\
\hline لّ يقل عن 250 & 251 & 265 & النعوومة (مُ//كنم) \\
\hline ل ع يقل عن 45 & 80 & 70 & وقتت الثماسك الابتت ائي (دقيقة) \\
\hline لا يزيب عن 10 ساعة & 6.0 & 4.5 & وقت التماسك النهائي (ساعة) \\
\hline لّ يقل عن 15 & 15.2 & 16.3 & تحمل الضغط (نبوتن/ملف2) \\
\hline لا يزيد عن 4 & 2.7 & 0.9 & الفقدان عند الحرق \% \\
\hline لا تزيد عن 1.5 & 1.15 & 1.3 & المو اد غير القابلة للأوبان \% \\
\hline$---\cdots--$ & 0.88 & 0.83 & عامل الإشباع الجيربي \% \\
\hline لا نزيخ عن 8 & 4.0 & 4.8 & محتوى ألو مينات ثلاثي الكالسيومه\% \\
\hline ل نزيخ عن 2.8 & 2.5 & 0 & محتو ث ثالث اوكسيد الكبريت\% \\
\hline لا تزيد عن 6 & 3.31 & 4.0 & محتو اوكسيب الحدبديلك \% \\
\hline$-\cdots-\cdots$ & 23 & 0 & ثاني أوكسيد النسليكون \% \\
\hline لا نزيد عن 5 & 2.3 & 4.4 & محتّوى أوكسيد المغنسيوم \% \\
\hline
\end{tabular}

*(مختبر قشم الهندسة المدنية/ كلية الهندسة/2.4

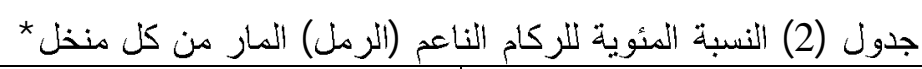

\begin{tabular}{|c|c|c|c|c|c|c|c|c|}
\hline \multicolumn{4}{|c|}{ م.ق.ع.رق 45 لسنة 1980} & \multicolumn{4}{|c|}{ مصدر الزكام الثناعم } & \multirow[b]{2}{*}{ حجי (مم) } \\
\hline دنظقة جن & منطقة تدرج(3) & تدر ج(2) & تخرجة (1) & الطوز & كركوك & الموصل & الز مادب & \\
\hline 100 & 100 & 100 & 100 & 100 & 100 & 100 & 100 & 9.5 \\
\hline $100-90$ & $100-90$ & $100-90$ & $100-90$ & 93.5 & 87.5 & 94.3 & 95.6 & 4.75 \\
\hline $100-95$ & $100-85$ & $100-75$ & $95-60$ & 79.6 & 90.1 & 80.3 & 75.2 & 2.36 \\
\hline $100-90$ & $100-75$ & $90-55$ & $70-30$ & 57.5 & 80.3 & 65.2 & 58.3 & 1.18 \\
\hline $100-80$ & $79-60$ & $59-35$ & $34-15$ & 43.5 & 65.7 & 45.6 & 28.2 & 0.600 \\
\hline $50-15$ & $45-15$ & $30-10$ & $20-5$ & 14.4 & 30.1 & 21.4 & 12.3 & 0.300 \\
\hline $15-0$ & $10-0$ & $10-0$ & $10-0$ & 3.8 & 5.3 & 4.3 & 6.4 & 0.150 \\
\hline 5- 0 & 5- 0 & 5- 0 & 5- 0 & 1.6 & 3.2 & 1.2 & 2.3 & 0.075 \\
\hline
\end{tabular}

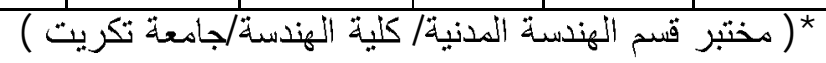

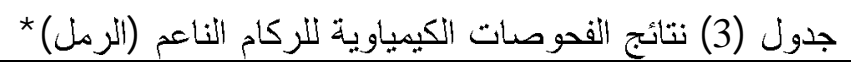

\begin{tabular}{|c|c|c|c|c|c|}
\hline \multirow{2}{*}{ م.ق.ع.زقم 45} & \multicolumn{4}{|c|}{ مصدر الزركام الثاعم } & \multirow{2}{*}{ الفحص الكيمياوي } \\
\hline & الطوز & كركوكت & الموصل & الز مادب & \\
\hline اققل هن 0.5 & 0.024 & 0.021 & 0.018 & 0.013 & نسبة المو اد الجبسية \% \\
\hline أقل من 2 & 0.94 & 0.791 & 0.712 & 0.672 & نسبة الاملاح الذائبة الكلية \% \\
\hline
\end{tabular}

*(مختبر قنم الهندسة المدنية/ كلية الهندسة/لجامعة تكريت )

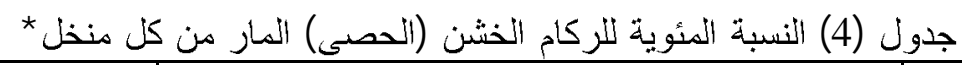

\begin{tabular}{|c|c|c|c|c|c|}
\hline \multirow{2}{*}{ م.ق.ع.زتّـ } & \multicolumn{4}{|c|}{ هصدز الركام الخثن } & \multirow{2}{*}{ حجم المنذل (مم) } \\
\hline & الطوز & كركو كت & 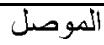 & الز مادي & \\
\hline $100-100$ & 100 & 100 & 100 & 100 & 50.0 \\
\hline $100-95$ & 100 & 98.1 & 96.2 & 100 & 37.5 \\
\hline $70-35$ & 70.1 & 65.2 & 55.1 & 67.3 & 19.0 \\
\hline $40-10$ & 9.9 & 12.2 & 26.3 & 18.6 & 9.5 \\
\hline $5-0$ & 0 & 0 & 2.1 & 1.4 & 4.75 \\
\hline $0-0$ & 0 & 0 & 0 & 0 & 0.075 \\
\hline
\end{tabular}

*( مختبر قسم الهندسة المدنبة/ كلية الهندسة/جامعة تكريت ) 


\begin{tabular}{|c|c|c|c|c|c|}
\hline \multirow{2}{*}{ م.ق.ع.رق لسنة 450} & \multicolumn{4}{|c|}{ مصدر الزركام الخشن } & \multirow{2}{*}{ الفحص الكيمياوي } \\
\hline & الطوز & كركوك & الموصل & الزمادي & \\
\hline لا تزيد عن 0.1\% & 0.0065 & 0.0058 & 0.0043 & 0.0051 & نسبة المو اد الجبسية \% \\
\hline لا تزيد عن 5\% & 0.096 & 0.084 & 0.061 & 0.073 & نسبة الاملاح الذائبة الكلية \\
\hline
\end{tabular}

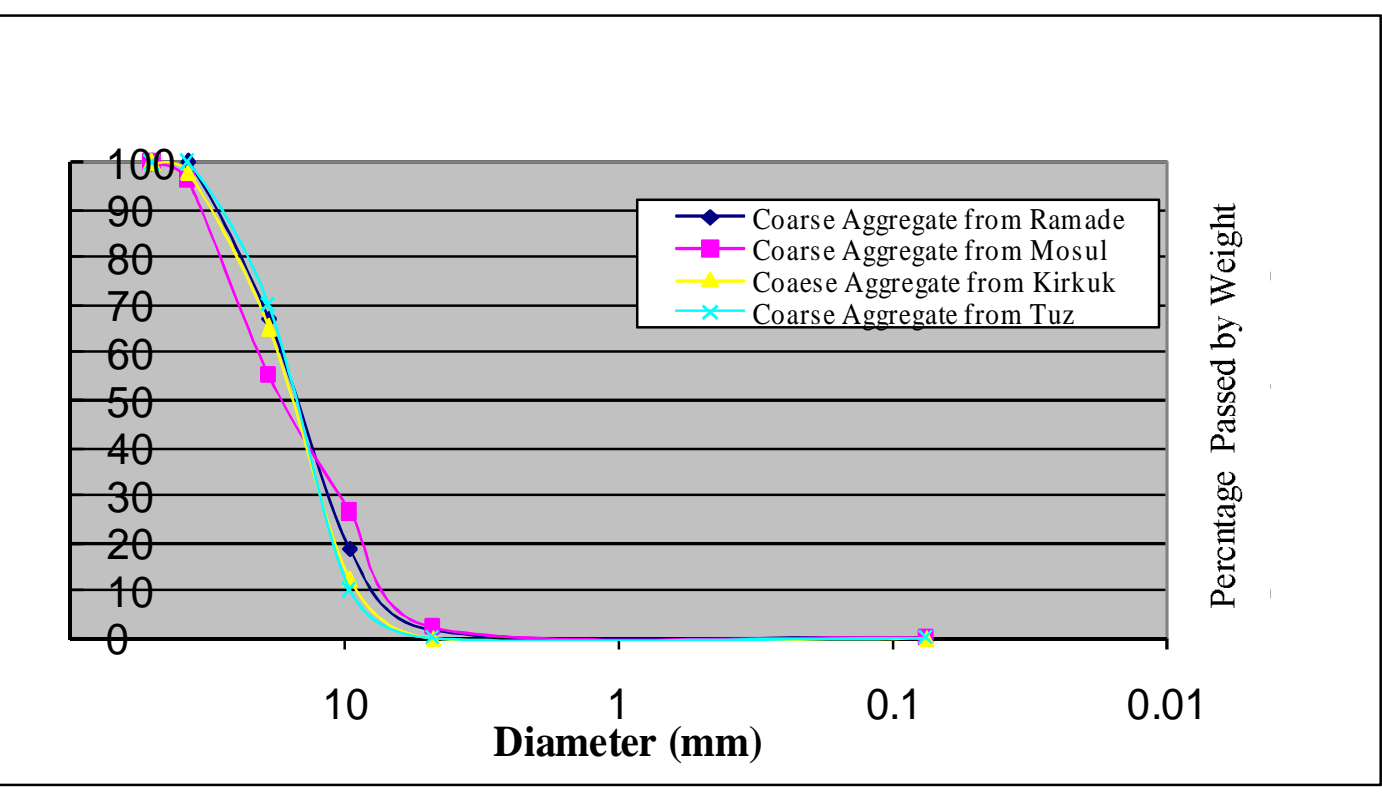

\section{شكل (1) يوضح التحليل المنظلي لدبيبات الركام الخشن (الحصى)}

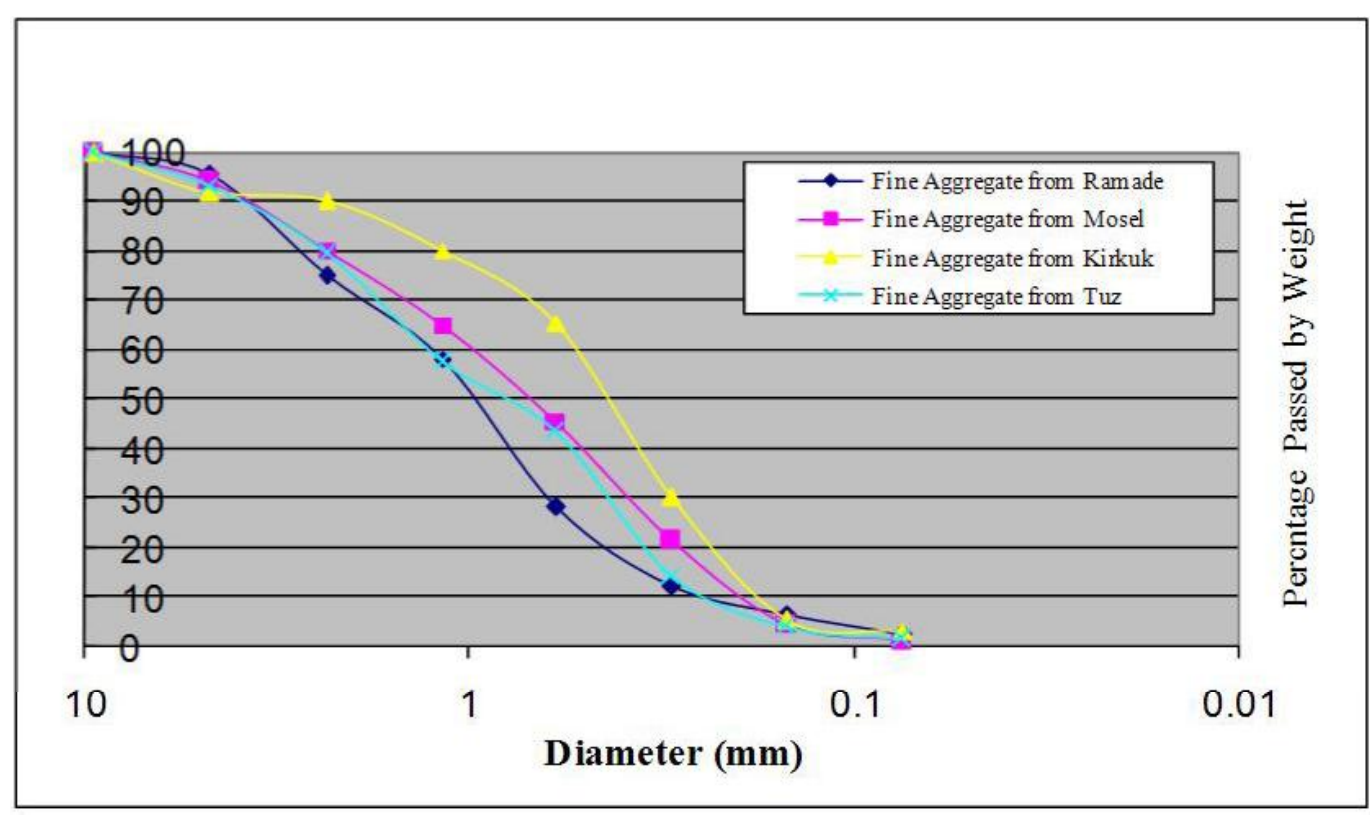

شكل (2) يوضح التحيل المنظبي لحبيبات الركام الناعم (الرمل) 


\section{تهيئة النماذج و الفحوصات المختبرية: -}

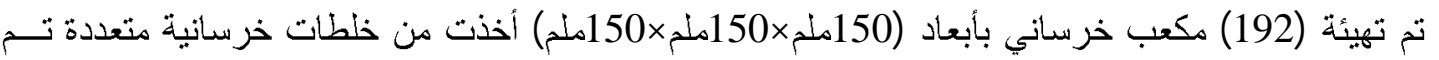

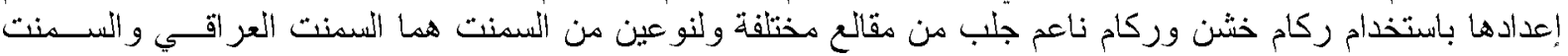

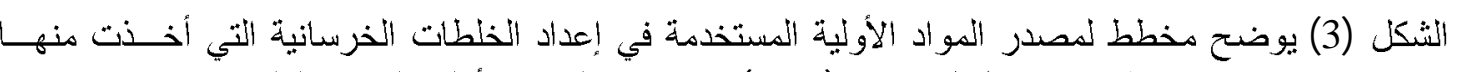

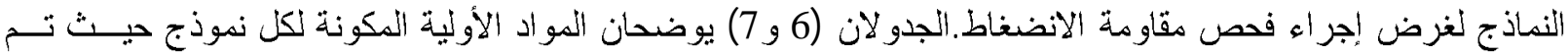

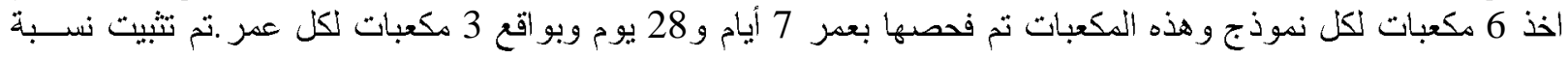

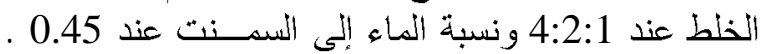

جميع الفحوصات و عملية اخذ النماذج تمت بموجب المو اصفة القياسية العر اقية رقم (52 ) لسنة 1972 الفئ.

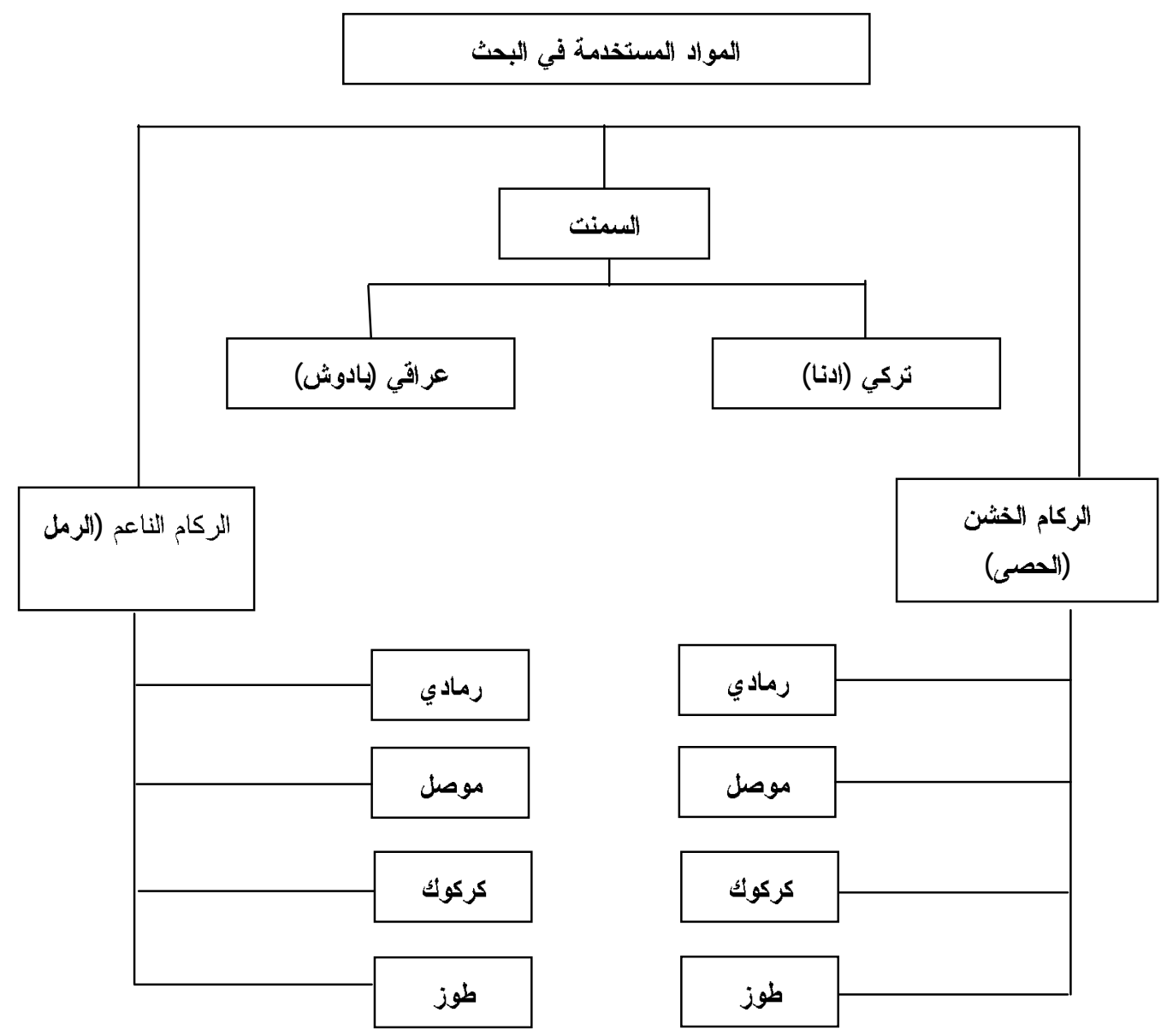

شكل(3) يوضح مصادر المواد الأولية المستخدمة في اعداد الخطات الخرسانية 


\begin{tabular}{|c|c|c|c|c|c|c|c|}
\hline \multicolumn{4}{|c|}{ 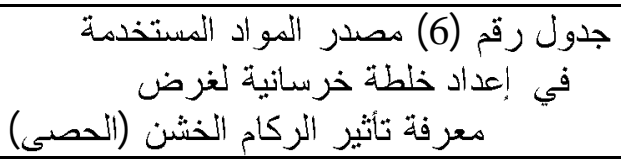 } & \multicolumn{4}{|c|}{ 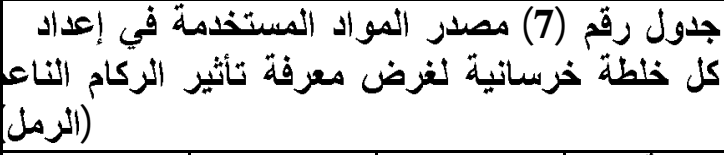 } \\
\hline السمنت & مصدز & ملحصدر & رالنمؤُج ج & نوع السمنت & مصدر الرهل & مصدر & النمونْ ج \\
\hline بادوش & الز مادي & الز مادي & A1 & بادوش & الرمادي & الر مادي & S1 \\
\hline بادوش & الز ماديب & الموصل & A2 & بادوش & الموصل & الر مادي & S2 \\
\hline بادوش & الز مادي & كركوكت & A3 & بادوش & كركوئك & الرمادي & S3 \\
\hline بادوش & اللز مادبي & الطوز & A4 & بادوش & الطوز & الرمادي & S4 \\
\hline بادوش & الموصل & الزل مادبي & A5 & بادوش & الزرمادي & الموصل & S5 \\
\hline بادوش & الكوصل & الموصل & A6 & بادوش & الموصل & الموصل & S6 \\
\hline بادوش & الموصل & كركوك & A7 & بادوش & كركوئك & الموصل & S7 \\
\hline بادوش & الموصل & الطوز & A8 & بادوش & الطوز & الموصل & S8 \\
\hline بادوش & كركوكت & الزماديب & A9 & بادوش & اللرمادي & كركوئك & S9 \\
\hline بأدوش & كركوت & الكوصل & $\mathrm{A} 10$ & بادوش & الموصل & كركوئك & S10 \\
\hline بادوش & كركوكت & كركوكت & A11 & بادوش & كركو كُ & كركوثك & S11 \\
\hline بادوش & كركوك & الطوز & A12 & بادوش & الطوز & كركوئك & S12 \\
\hline بادوش & الطوز & الزر مادي & A13 & بادوش & الز مادي & الطوز & S13 \\
\hline بادوش & الطوز & الموصل & A14 & بادوش & الموصل & الطوز & S14 \\
\hline بادوش & الطوز & كركوكت & A15 & بادوش & كركوئك & الطوز & S15 \\
\hline بادوش & الطُوز & الطوز & A16 & بادوش & الطوز & الطوز & S16 \\
\hline ادنا & الز مادي & الزمادي & A17 & |دنا & الز مادي & الرمادي & S17 \\
\hline ادنا & الزرمادي & الكوصن & A18 & إنا & الموصل & الرمادي & S18 \\
\hline ادنا & الز مادبي & كركوكت & A19 & (ניنا & كركوئك & الرمادي & S19 \\
\hline ادنا & الز مادبي & الطوز & A20 & إنا & الطوز & الرمادي & S20 \\
\hline ادنا & الكوصل & الز ماديب & A21 & (إنا & الز مادي & الموصل & S21 \\
\hline ادنا & الكوصل & الكوصن & A22 & إلنا & الموصل & الموصل & S22 \\
\hline ادنا & الموصل & كركوكت & A23 & إدنا & كركوئك & الموصل & S23 \\
\hline ادنا & الكوصل & الطوز & A24 & إدنا & الطوز & الموصل & S24 \\
\hline ادنا & كركوك & الزرمادبي & A25 & إدنا & الزرمادي & كركوئ & S25 \\
\hline ادنا & كركوكت & المو صل & A26 & (إنا & الموصل & كركوئك & S26 \\
\hline ادنا & كركوكت & كركوك & A27 & إدنا & كركوئك & كركوئك & S27 \\
\hline ادنا & كركوك & الطوز & A28 & إدنا & الطوز & كركوثك & S28 \\
\hline ادنا & الطوز & الزرماديب & A29 & (ادنا & الر مادي & الطوز & S29 \\
\hline ادنا & الطوز & الموصن & A30 & إدنا & الموصل & الطوز & S30 \\
\hline ادنا & الطوز & كركوك & A31 & أدنا & كركوثك & الطوز & S31 \\
\hline ادنا & الطوز & الطوز & A32 & إنا & الطوز & الطوز & S32 \\
\hline
\end{tabular}

تعتبر مقاومة الخرسانة للانضغاط من أهم خو اصها التي تعطي صورة شاملة عن نوعيتها ودليل جيد لمعظم خو اصها

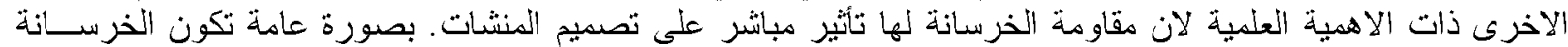

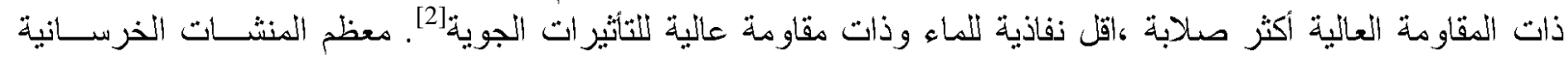

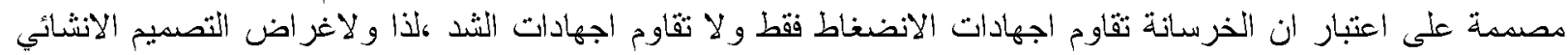

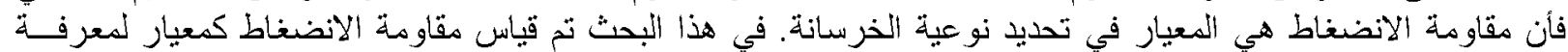

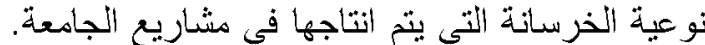

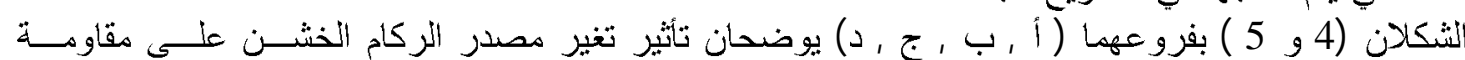

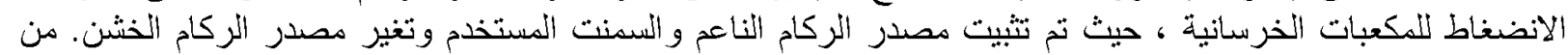

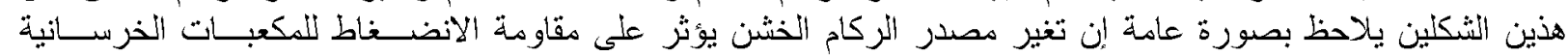

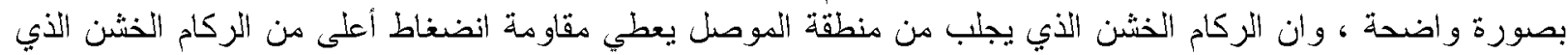

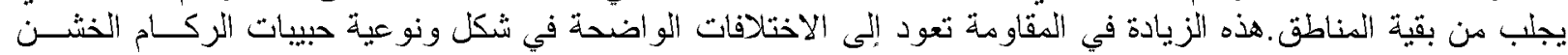

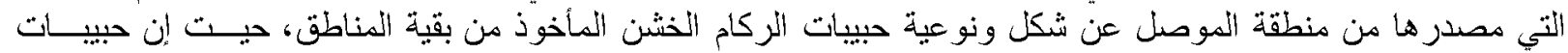
الركام الخشن لمنطقة الموصل عادة تكون ذات أوجه مضنعة وخشنة المفلمس السطحي في حين إن حبيبات الركام الخثــن 
لبقية المناطق تكون رقاثقية الثكل وذات ملمس سطحي ناع. وكما موضح في الشكل (6). لقد ذكر الخفلف(1984) [1] بأنه

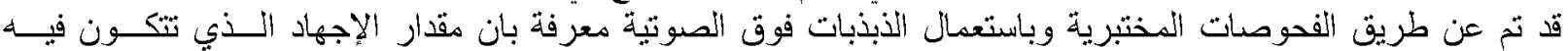

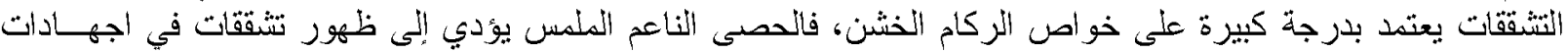

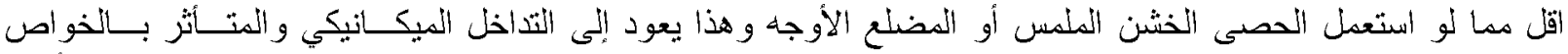

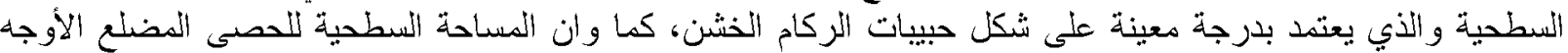

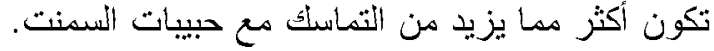

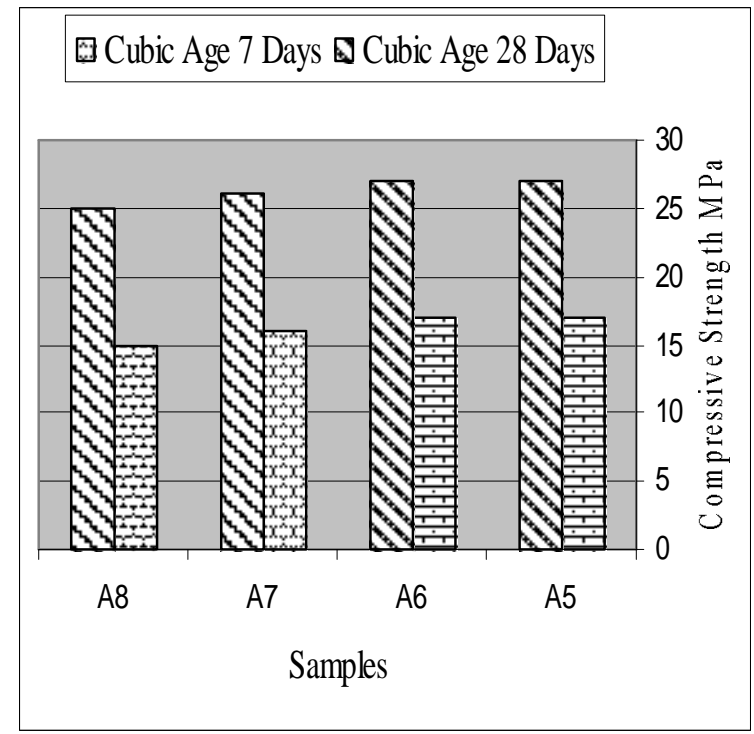

الثكل( 4 -ب ) الزمل المستخدم من الموصل

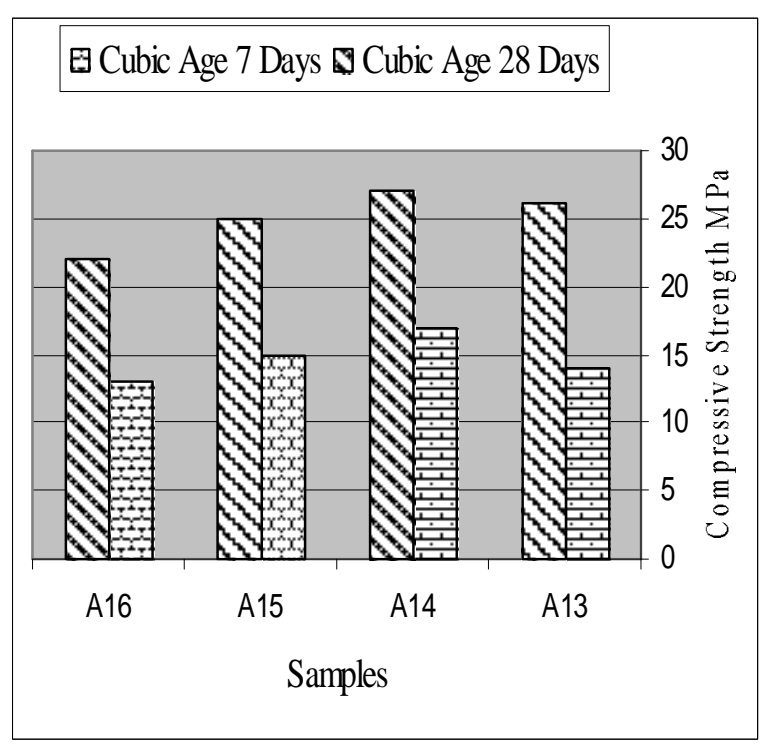

الشكل ( 4 - 2ـ ) الزمل المستخدم من الطوز

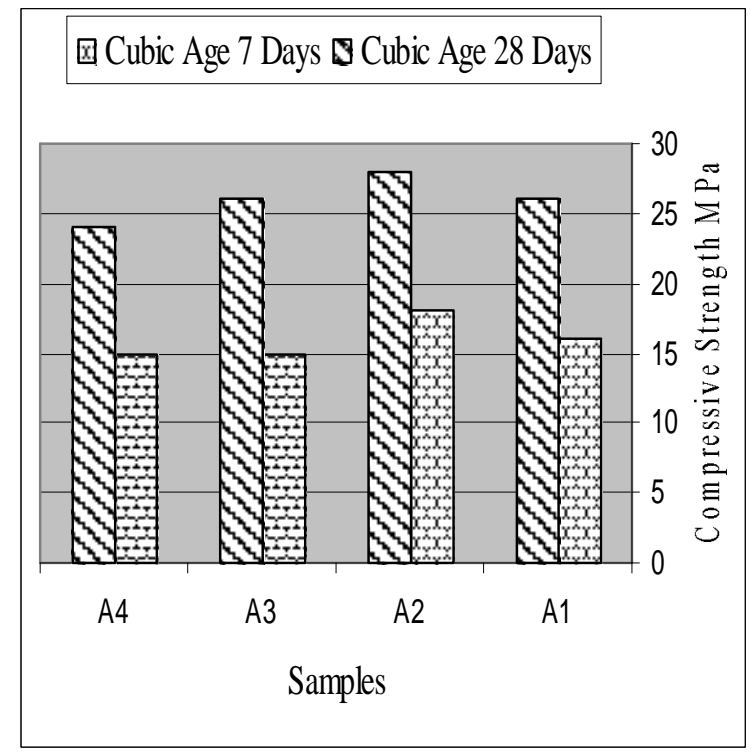

الثنكل( 4 - أ ) الرمل المستخدم من الزممادي

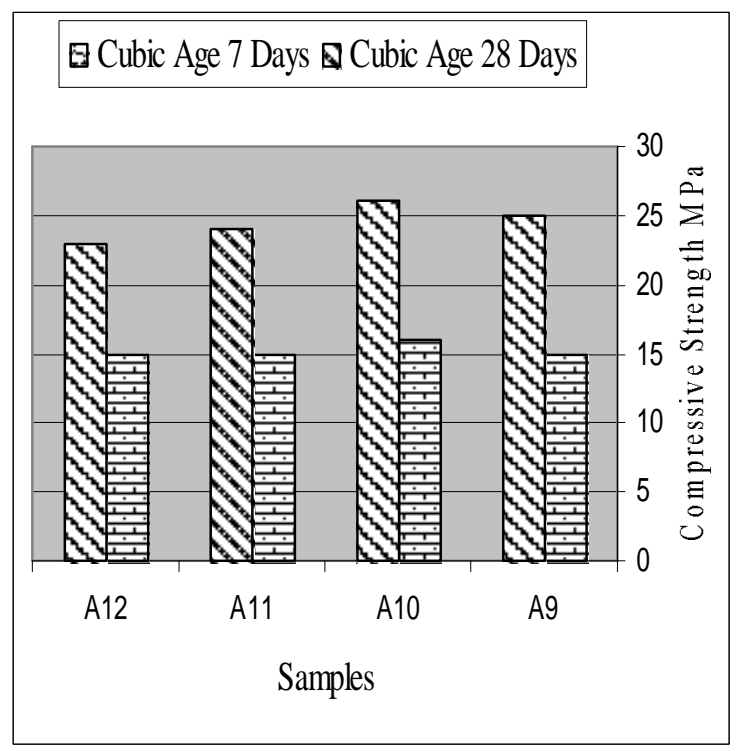

الثنكل ( 4 -ج ) الزرمل المستخدم من كركوثك

الثكل رقم (4) تأثير تغيير مصدر الزكام الخثن على قابلية

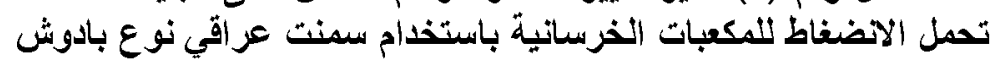




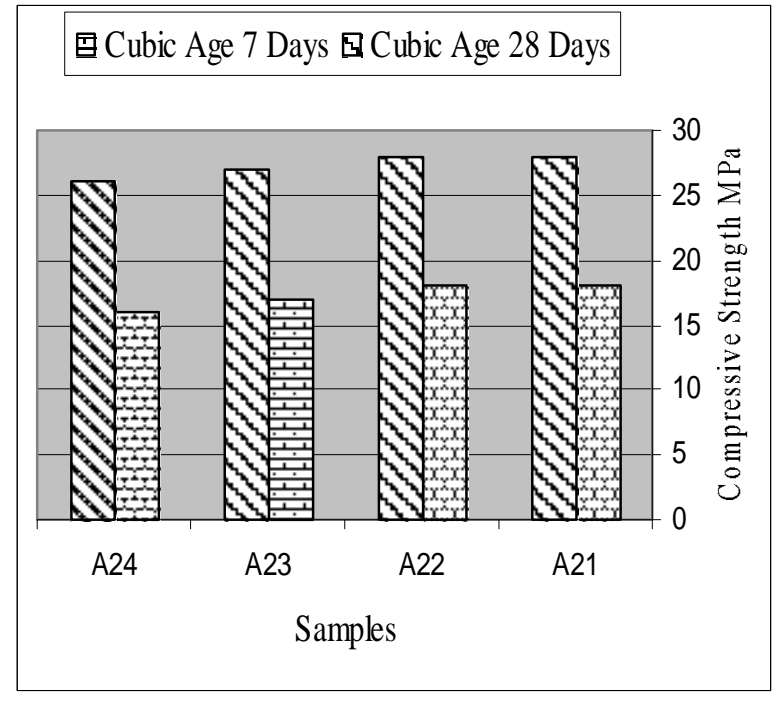

الثُكل ( 5 - ) ) الحصى المستخدم من الموصل

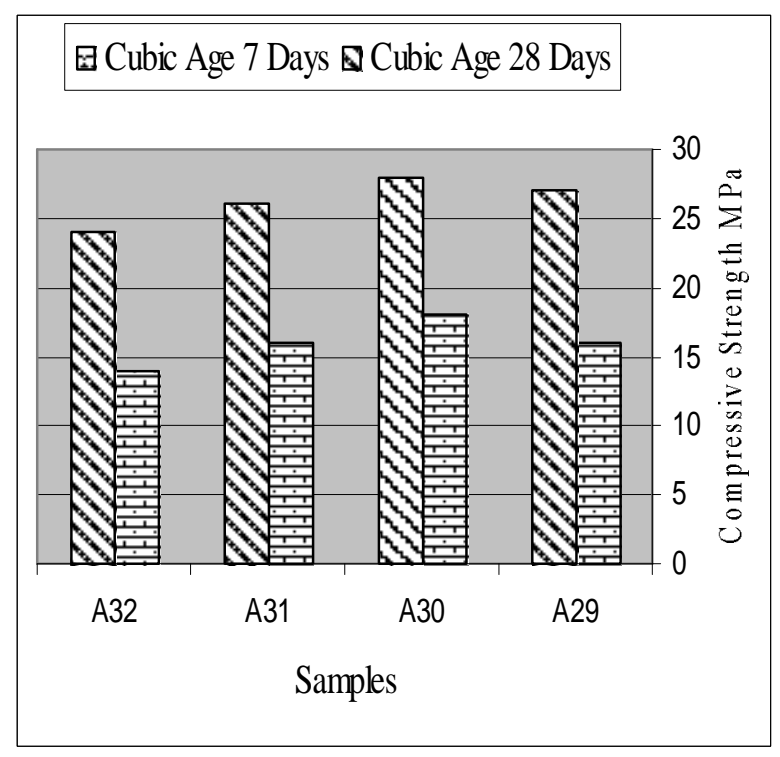

الثنكل ( 5 -1 ) العصى المستخدم من الطوز

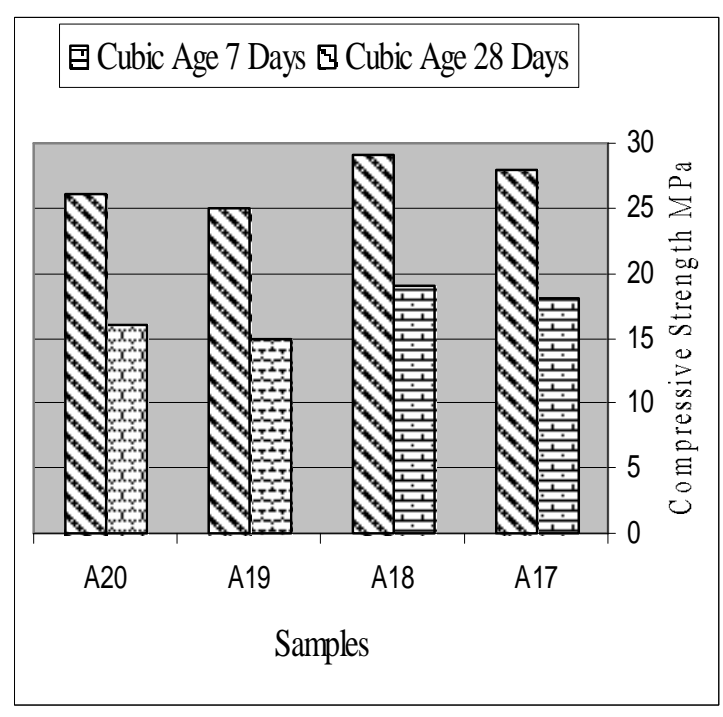

الثُكل ( 5 -1 ) الحصى المستخدم من الرمادي

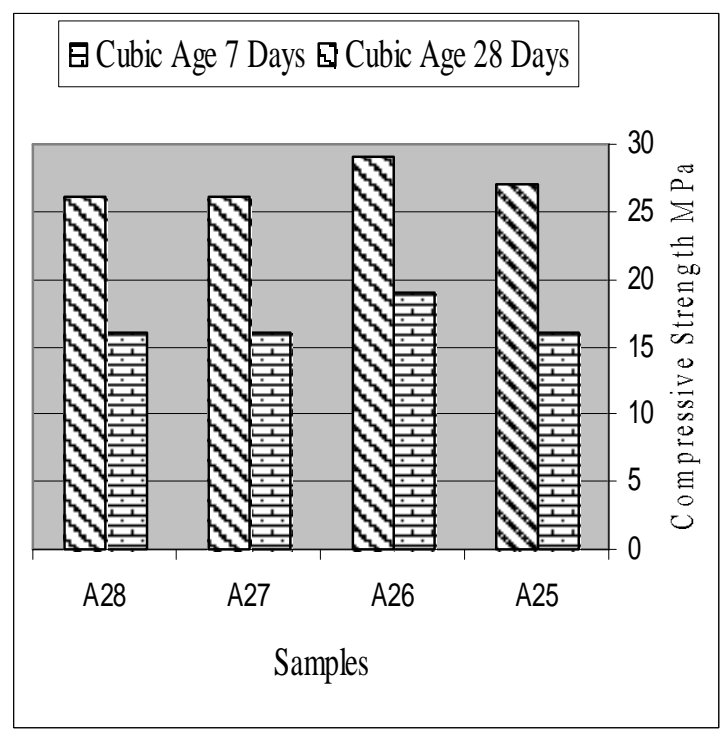

الثُكل ( 5 -ج ) الحصى المستخذم من كركوك

$$
\begin{aligned}
& \text { الثكل رقم (5) تأثير تغيير دصدر الزكام الخشن على قابلية تحمل }
\end{aligned}
$$

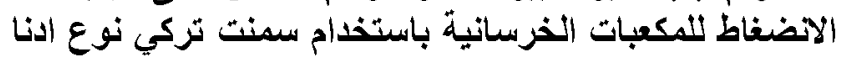

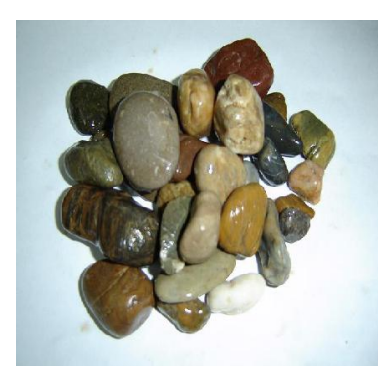

1. حصى منطقة الطوز
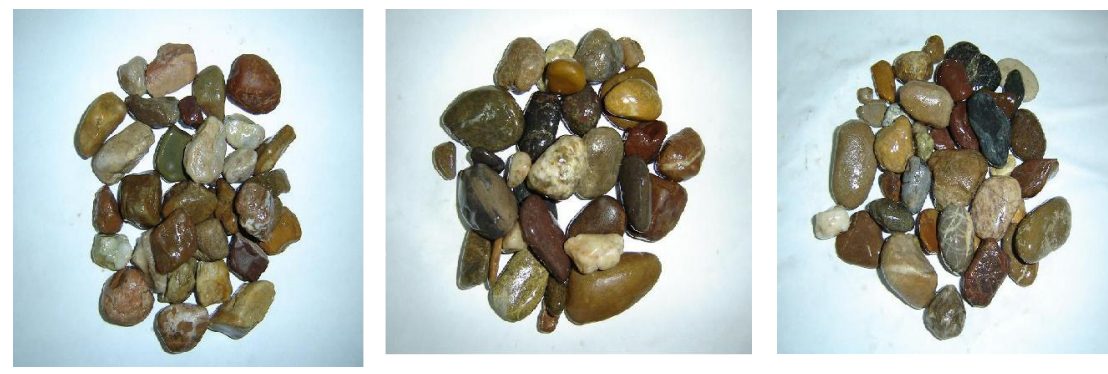

حصى منطقة كركوك 3.
حصى منطقة الموصل في

حصى منطقة الرمادي.4 شكل (6 ) يوضح نماذج للركام الخثن المستخدم في انبحث 
الثكلان (7 و 8 ) بفروعهما ( أ , ب , ج , د) يوضدان تأثير تغير مصدر الركام الناعم (الرمل) على قابلية

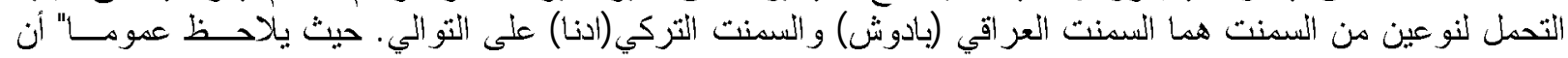

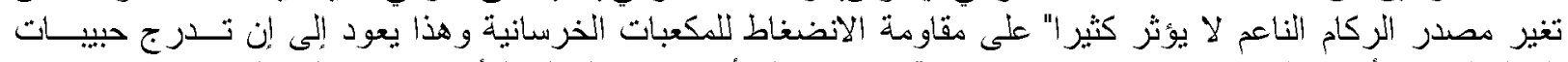

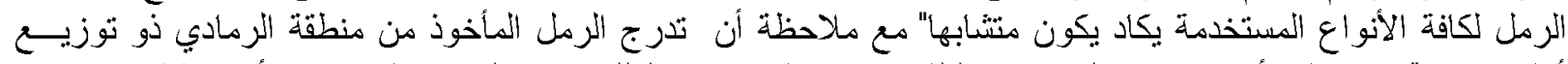

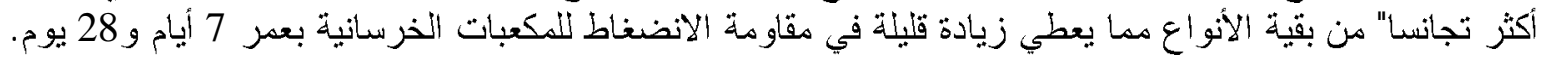

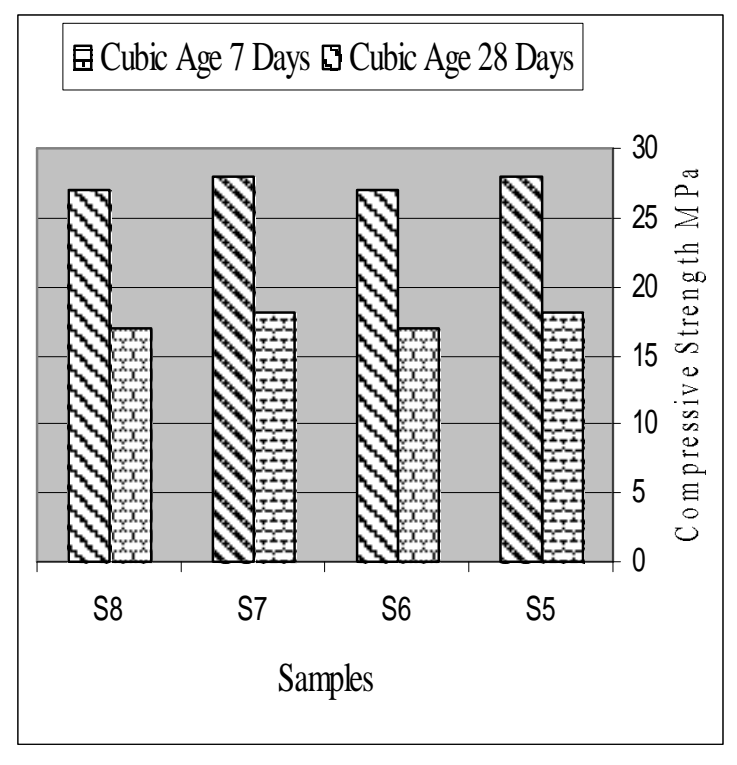

الثكل ( 7 - ) العصى المستخدم من الموصل

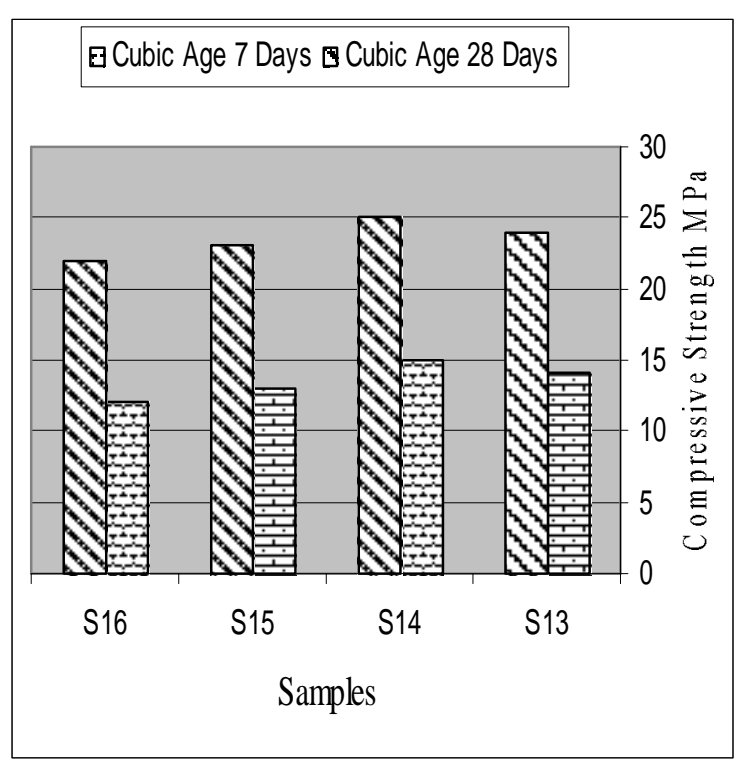

الثكل ( 7 -ـ ) العصى المستخدم من الطوز

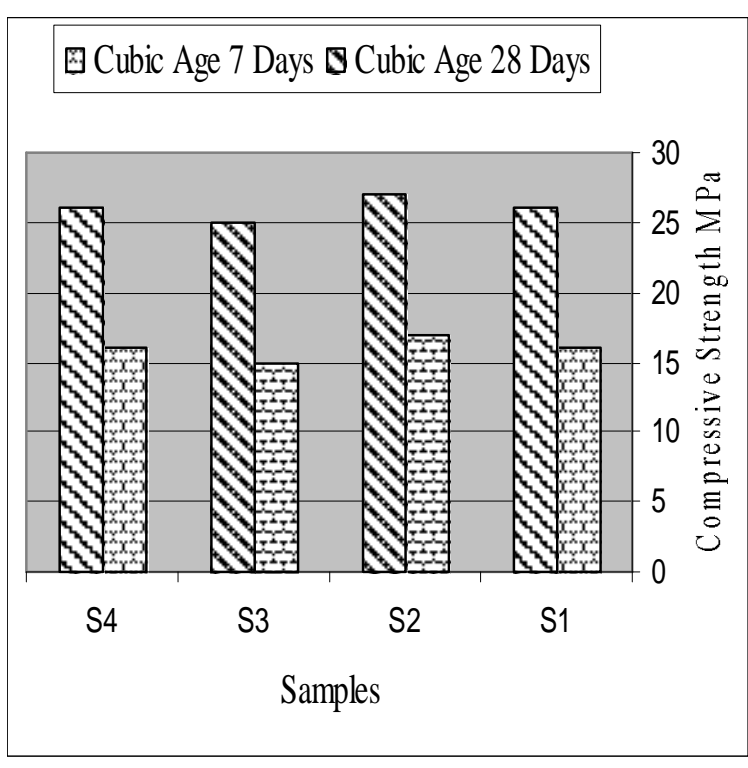

الشكل ( 7 -أ ) الحصى المستخدم من الرمادي

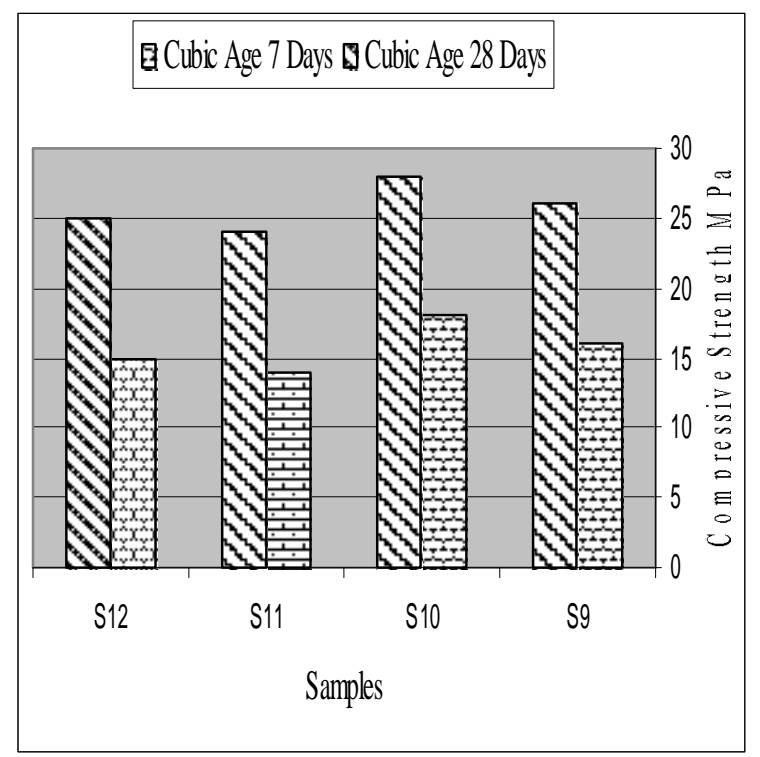

الثكل ( 7 -ج ) الحصى المستخدم من كركواث

الثكل رقم (7) تأثير تغيير مصدر الركام الناعم على قابلية

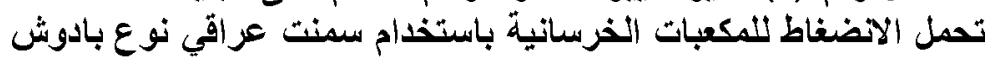



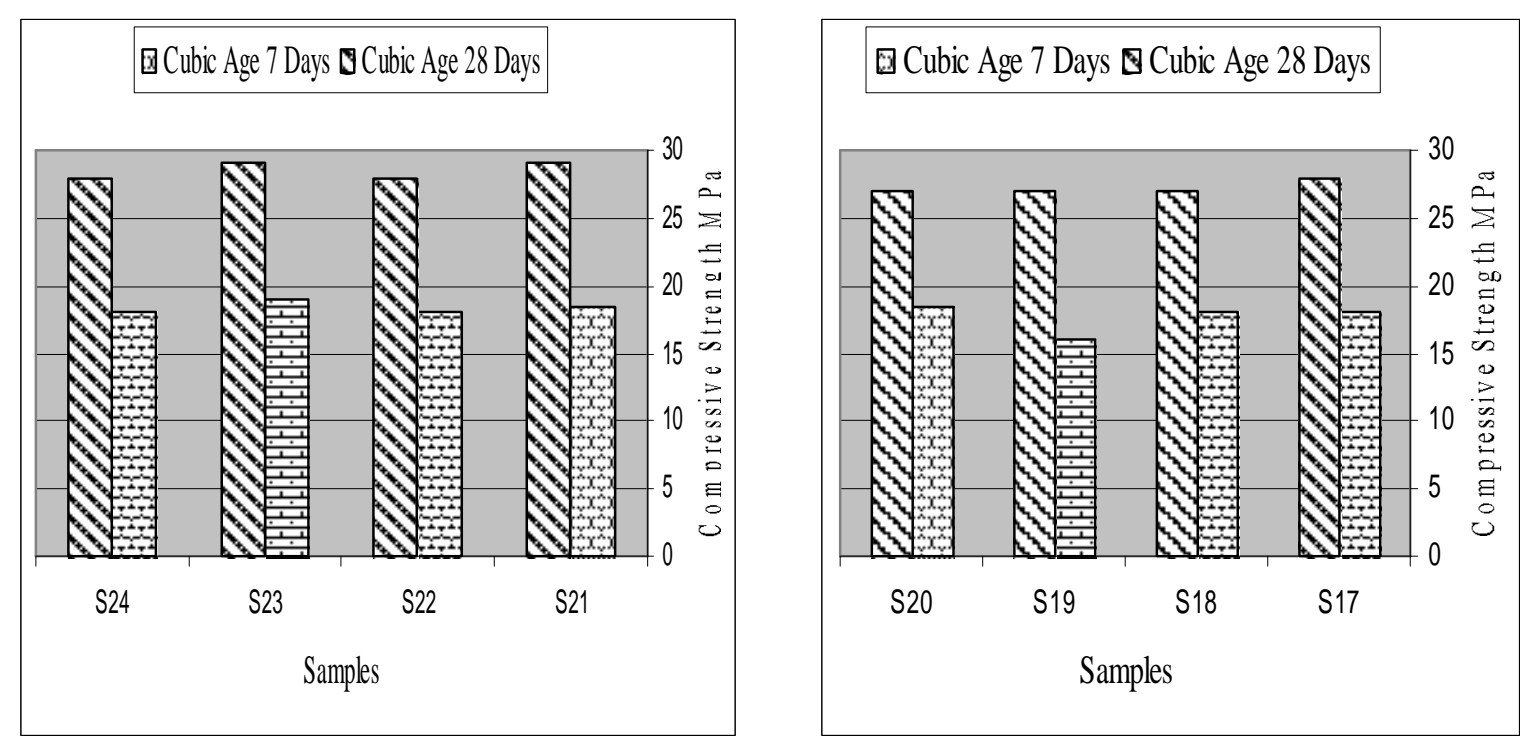

الثنكل ( 8 - (ب ) الحصى المستخدم من الموصل
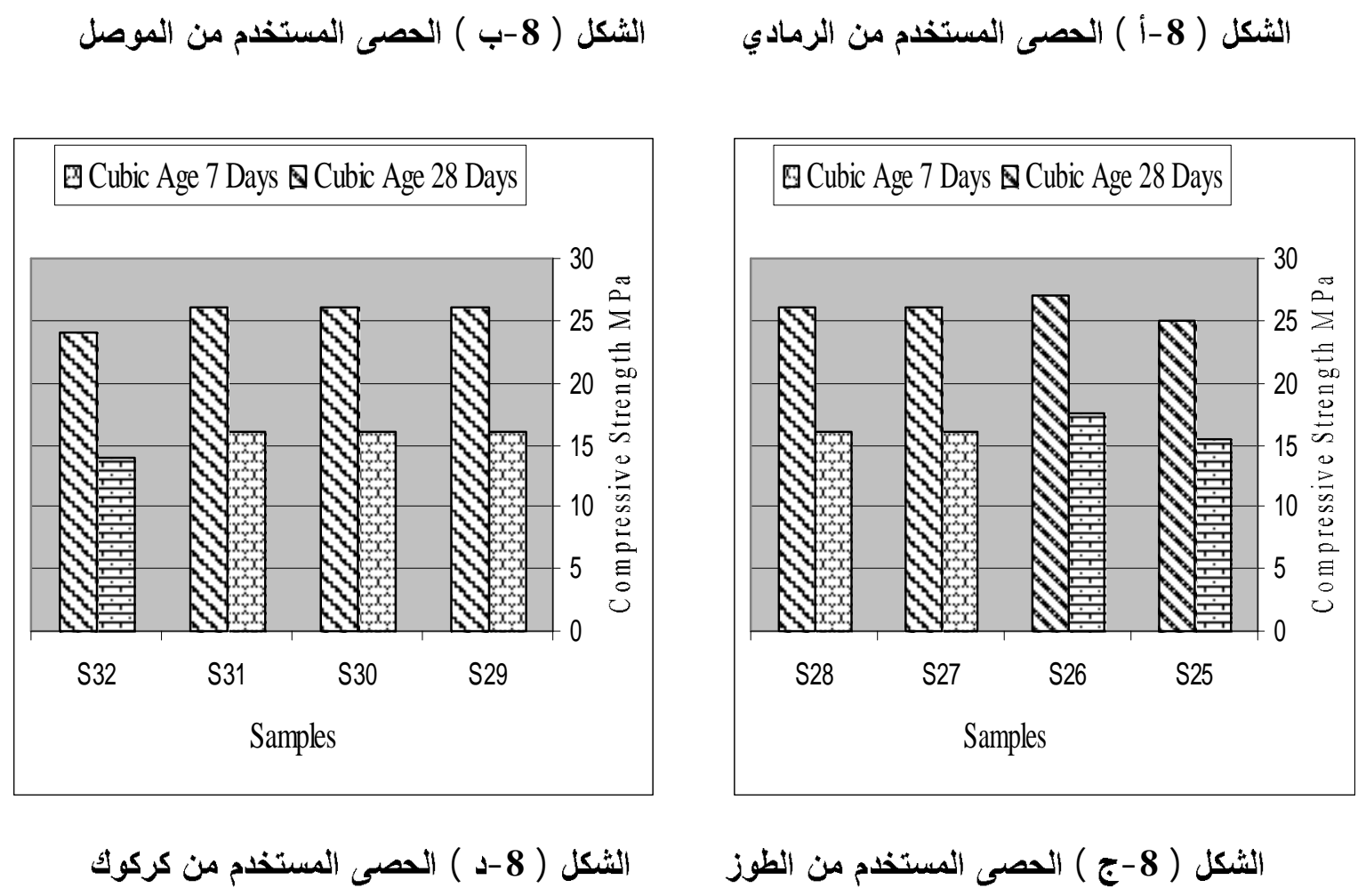

الأشكال ( 4 ، 5 , 7 , 8 ) ثتير إلى وجود انخفاض واضح في قيم مقاومة الانضغاط للخنطات التي تم فيها

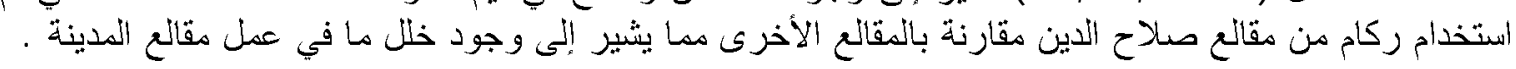

الثكل(9) و الشكل (10) ، يوضحان تأثير تغبر نوعية السمنت على قابلية تحمل الانضغاط للمكعبات

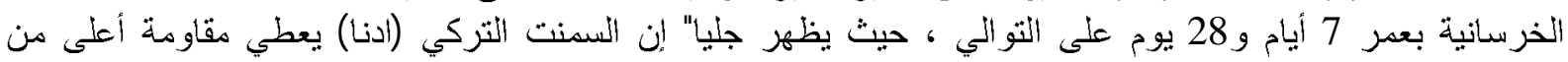

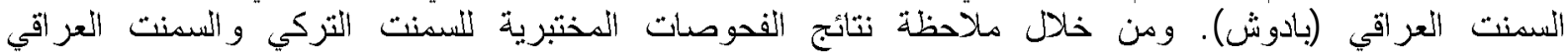

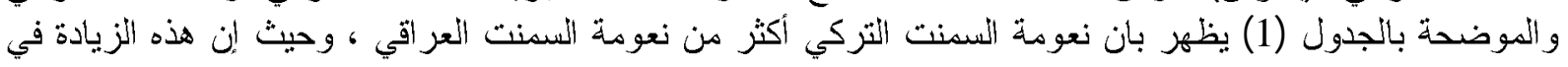




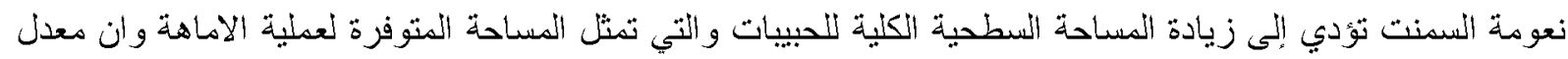

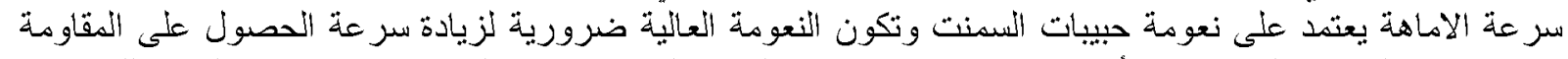

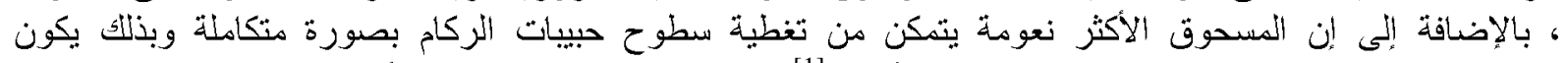

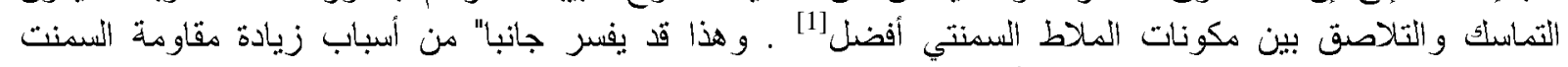

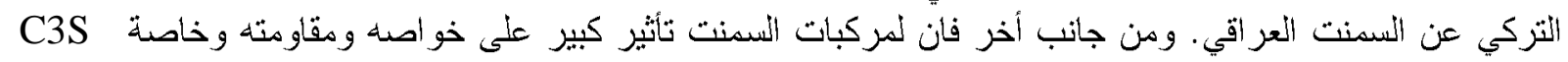

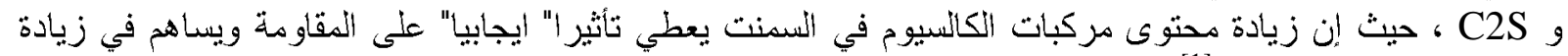

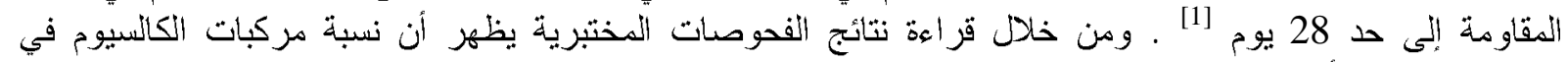

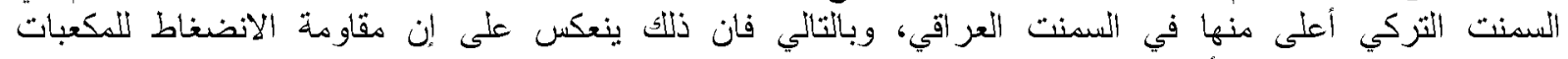

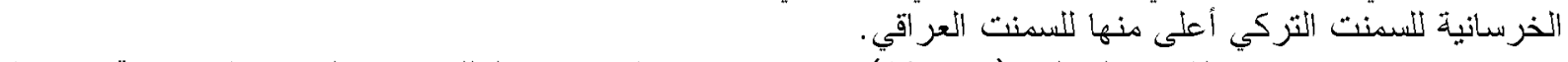

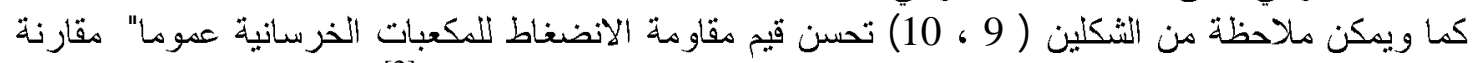

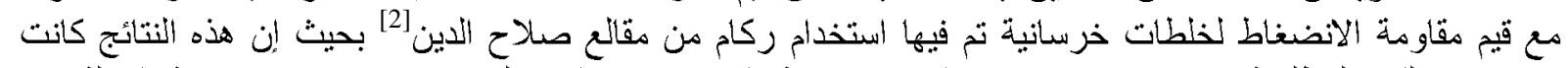

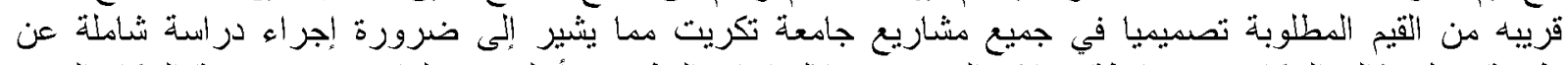

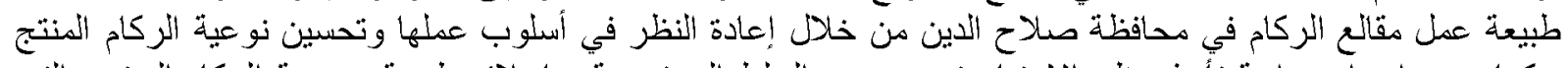

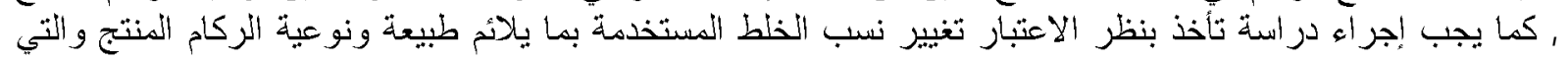

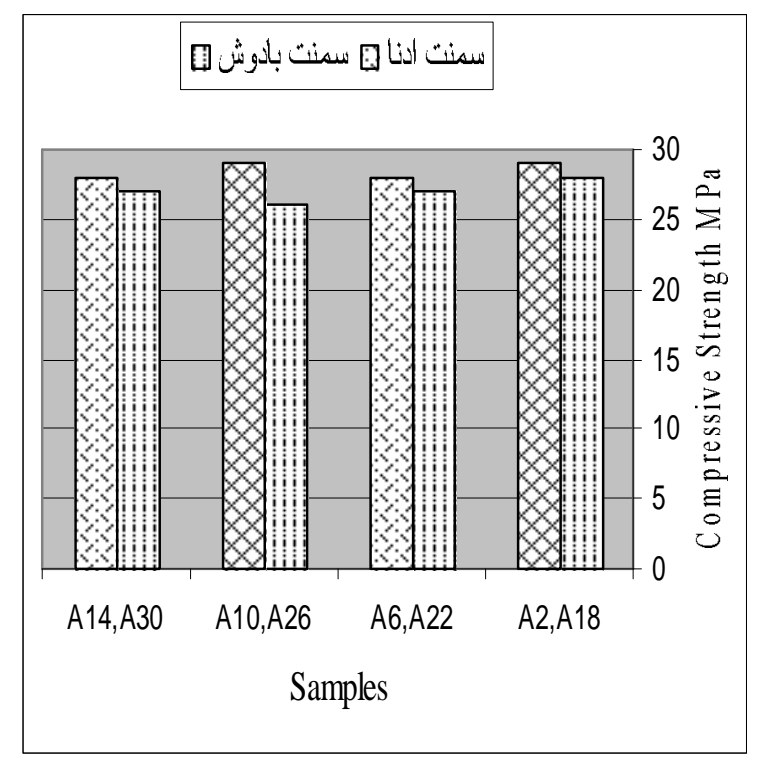

شكل رثم (10) يوضح تأثير تغيير نوع السمنت على التئي

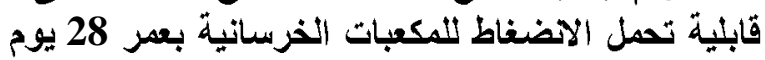

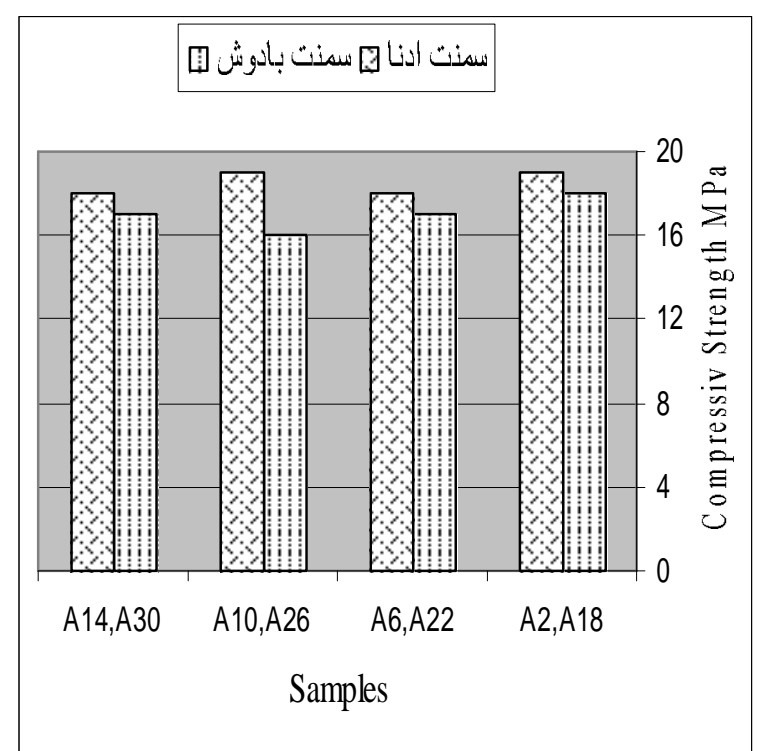

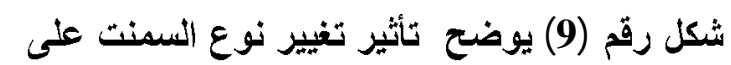

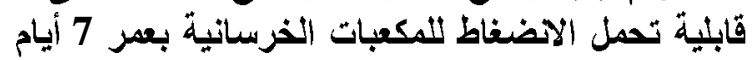

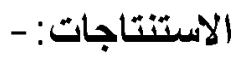

من خلال تحليل النتائج التي تم الحصول عليها من الفحوصات المختبرية يمكن أن تجمل أهم الاستتتاجات بما يلي: -

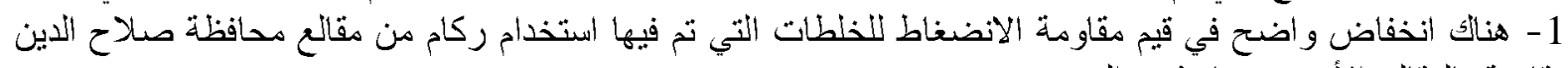

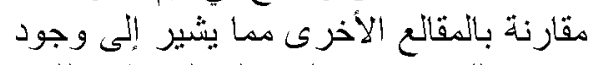
خلل ما في عمل مقالع المدينة ينطلب تحديده من خلال استكمال إجز اء بقية الدر اسات مستقبلا كنسب الخلط

المستخدمة مثلا.

2 - أكدت النتائج صحة الاستنتاجات التي تشير إلى أن تأثير الركام الخشن (الحصى) على قابلية تحمل الانضغاط

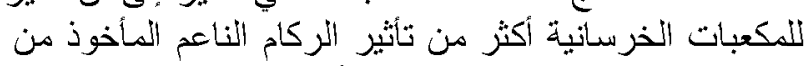

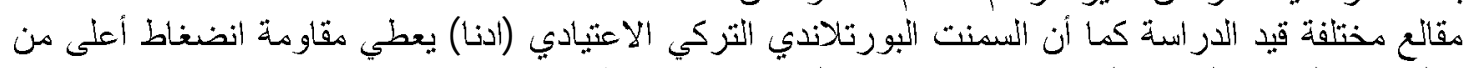

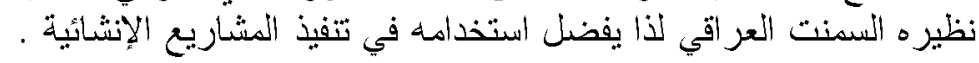

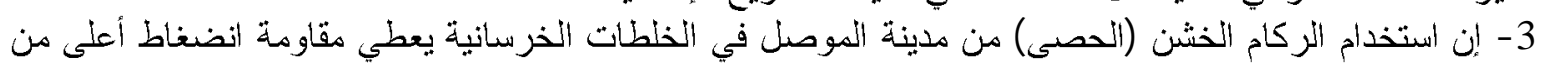

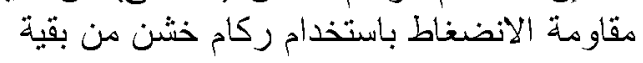


المناطق(الزرمادي , كركوك , الطوز) كما أن استخدام ركام ناعم من منطقة (الرمادي) يعطي زيادة طفيفة في

4 - يلاحظة بصورة رة عامة تحسن مقاومة الانضغاط للمكعبات الخرسانية الناتجة عن استخدام مقالع المدن المجاورة

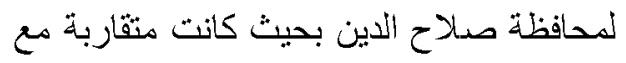

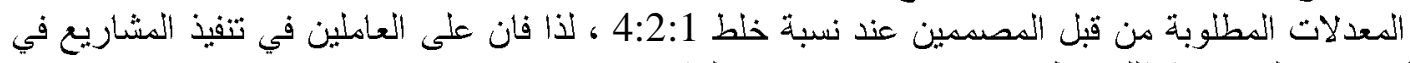

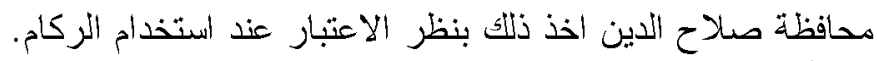

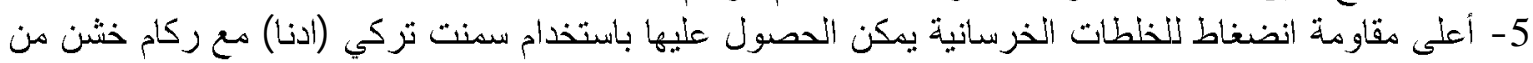
هديذة الموصل وناعم من مدينة الزمادي، لذا يفضل استخدام هذه المو اد في إعداد الخلطات الخدان الخرسانية

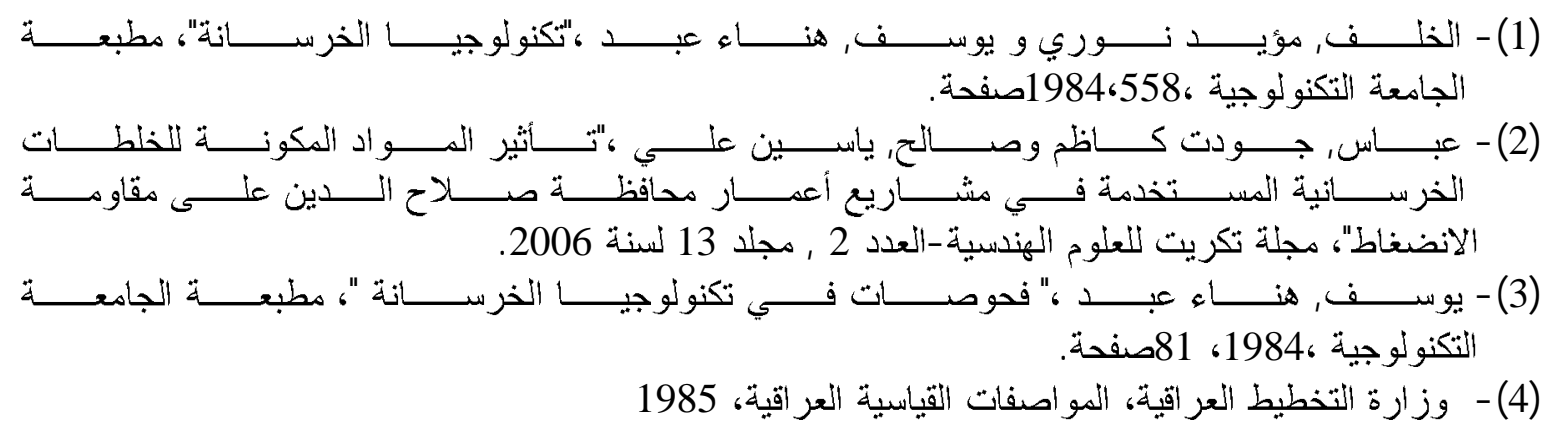

(5) - Neville A.M.," Properties of Concrete", Pitmum,1978.

(6) - Orchard D.F.," Concrete Technology :Properties and

Testing of Aggregate ", Vol. 3, Applied Science,1976. 